\title{
Economics
}

\section{Technical Efficiency of Poultry Egg Production in Ibadan Metropolis, Oyo State, Nigeria}

\author{
Otunaiya Abiodun Olanrewaju, ${ }^{1,}$, Adeyonu Abigail Gbemisola ${ }^{2}$, Bamiro Olasunkanmi Moses ${ }^{2}$ \\ ${ }^{1}$ Department of Agricultural Economics and Farm Management, College of Agricultural Sciences, Olabisi Onabanjo University, Yewa \\ Campus, Ayetoro, Ogun State, Nigeria \\ ${ }^{2}$ Department of Agricultural Economics and Extension, College of Agricultural Sciences, Landmark University, Omu-Aran, Kwara State, \\ Nigeria
}

Email address:

aootunaiya@gmail.com (A. O. Otunaiya)

\section{To cite this article:}

Otunaiya Abiodun Olanrewaju, Adeyonu Abigail Gbemisola, Bamiro Olasunkanmi Moses. Technical Efficiency of Poultry Egg Production in Ibadan Metropolis, Oyo State, Nigeria. Economics. Vol. 4, No. 3, 2015, pp. 50-56. doi: 10.11648/j.eco.20150403.12

\begin{abstract}
This study investigates the technical efficiency of poultry egg farmers in Ibadan metropolis, Oyo state, Nigeria. The data for the study were collected from 107 poultry egg farmers with the aid of structured questionnaire. The data collected were analyzed using descriptive and inferential statistics based on the objectives of the study. The results show that the mean age of the respondents was 49 years, about $89 \%$ of them were married and the majority of them are well educated. A higher percentage of them (87\%) were members of cooperative society; stock their farms with a-day-old chicks (68\%) and were owners of the poultry farms (61\%). The Maximum Likelihood Estimates (MLEs) of the production function showed that quantity of feed and drugs significantly determined poultry egg production. The results of inefficiency model revealed that years of respondents experience in egg poultry egg production, membership of cooperative society, system of management and stock type significantly lowers farm technical inefficiency. The study recommends training of the poultry egg farmers on modern techniques of keeping layers and benefits of being membership of cooperative society.
\end{abstract}

Keywords: Technical efficiency, Poultry, Egg production, Inefficiency, Nigeria

\section{Introduction}

The agricultural sector in Nigeria is the most important non-oil economic activity; it is also the single largest employer of labor force, employing about 70 percent of its workforce $(1,2)$ and contributed $40.07 \%$ and $22 \%$ (pre and post debasing respectively) of Gross Domestic Products (GDP) in 2010 and 2014 respectively (1). The sector consists of crops, fishery, livestock and forestry sub-sectors. The Agricultural Gross Domestic Product (GDP) contributed by sub-sector are; Crops (36.40\%), Livestock (2.61\%), Fisheries $(1.34 \%)$ and Forestry $(0.52 \%)$. Over $80 \%$ of the country's population living in the rural areas is directly or indirectly dependent on agriculture for its livelihood (1).The Nigerian's livestock population consist of 16.3 million Cattle; 40.8 million Goat; 27 million Sheep; 3.7 million Pigs and 151 million poultry (3). Going by this figure, poultry alone constitutes more than $60 \%$ of the total livestock production, indicating the dominance of poultry sub sector in the livestock industry.
The poultry industry plays important roles in the development of Nigerian economy. The industry provides employment opportunities for the populace, thereby serving as a source of income to the people. Also, it provides a good source of animal protein in meat and eggs which have a high nutritional value $(4,3)$. Animal protein sources include fish, eggs, poultry meat, beef, milk, bacon, pork and mutton. In Nigeria, the three most popular are fish, beef, and poultry meat (chicken) and eggs (5). Poultry meat and eggs are palatable and generally acceptable with little or no cultural and religious boundaries in Nigeria. Chickens and eggs contribute to a nutritious, balanced diet, which is especially important for children, nursing mothers and people who are ill (6). Eggs are an excellent source of iron, zinc and vitamin A, all of which are essential for health, growth and well being; egg is a complete protein with excellent quality $(7,8)$.

In Nigeria, despite growth in the egg production industry 
since 2000, local demand has not been matched by local supply. In 2011, the Nigerian egg production stood at 636.000 million metric tons (2).With population of about 165 , million in 2011 (1), a huge demand- supply gap was created given the one egg per day advocacy. Optimum production efficiency can be achieved by effective utilization of the available inputs thus improving upon the outputs. The efficiency with which farmers use available resources and improved technology is important in agricultural production (9). Increased efficiency associated with the quality of resources used and the right choice of better technology, reduce wastage and increase production Improvement of efficiency and fulfillment can be the most effective methods to realize production development and sustainability of the poultry sub-sector. $(10,11)$

Some of the available literature and studies on technical efficiency of poultry egg farmers in Nigeria include: $(12,13$, 14,15 , and 11).They all focused on technical efficiency of poultry egg production generally. This study distinguishes itself from these other studies in terms of the methodology adopted. The study included stock type and farm ownership status in the technical inefficiency model of the farmers. This makes the model superior to the ones used by other researchers in the country. Also, the time lag between this study and others of its kind makes it unique, given the current rebasing of the nation's GDP. To this end, the objective of this study therefore, is to analyze technical efficiency of poultry egg farmers in Ibadan metropolis. The study will specifically describe the socio-economic characteristics of the poultry egg farmers in the study area; analyze the technical efficiency of the farmers and determine the factors contributing to technical inefficiency in poultry egg production.

\section{Methodology}

\subsection{The Study Area}

The study was carried out in Ibadan metropolis which is made up of 11 Local Government Areas (LGAs). It is the capital of Oyo state, southwestern Nigeria. It is the third largest city in Africa after Cairo and Johannesburg. The city has a population of 1,338,659 in2006and more than 96 per cent of the inhabitants are Yoruba (17). Ibadan has a tropical wet and dry climate, with a lengthy wet season and relatively constant temperatures throughout the course of the year. This good weather condition makes poultry business common among farmers in the area.

\subsection{Data and Sampling Techniques}

Primary data used for this study were obtained through the use of pre-tested, well-structured questionnaire. The tool was used to collect information on respondents' socioeconomic characteristics as well as egg outputs and inputs from poultry egg farmers.

A two-stage sampling technique was employed in selecting the respondents. The first stage involved purposive selection of two out of 11 LGAs in the metropolis based on higher population of poultry egg farmers in those areas (Lagelu and Oluyole).The list of the poultry egg producers in the selected LGAs was obtained from Poultry Association of Nigeria, Oyo state chapter (PANOY). The second and final stage of the sampling involved the random selection of respondents from each of the selected LGAs proportionate to size. In all, 130 poultry farmers were interviewed and 107questionnairehas meaningful information for analysis.

\subsection{Analytical Tools}

Descriptive and inferential statistics were employed in the analysis. Descriptive statistics such as: means, standard deviation, frequencies and percentages were used to describe the socio-economic characteristics of the respondents, input and output variables and the distribution of technical efficiency levels. The stochastic production frontier function that incorporated inefficiency factors was estimated using Maximum Likelihood Estimation (MLE) technique to obtain farm specific technical efficiencies as well as their determinants following (18).

\subsubsection{Model Specification}

The stochastic production frontier function was specified as:

$$
Y=f\left(X_{i}, \beta\right) \exp \left(e_{i}\right)
$$

Where,

$Y=$ egg output in ith farm (measured in physical terms of number of eggs produced).

$X_{i}=$ Vector of inputs used by the ith farmer.

$\beta=$ vector of unknown parameters

$e_{i}=V_{i}-U_{i}$ (Composite error term).

Where,

$V_{i}=$ Random variable assumed to be independently distributed $\mathrm{N}(0,1)$ and independent of $U_{i}$

$U_{i}=$ Random variable that accounts for technical inefficiency and assumed to be independently

distributed as truncation of the normal distribution with mean $\mu$ and variance.

$$
\mu=A K
$$

Where,

$\mathrm{A}=\mathrm{I} \times \mathrm{e}$ Vector of farm/farmers characteristics that may cause inefficiency.

$\mathrm{K}=\mathrm{e} \times \mathrm{I}$ Vector of unknown parameter to be estimated.

The farm level stochastic production frontier functions that signify the maximum possible output $\left(Y^{*}\right)$ can then be denoted as:

$$
Y^{*}=\mathrm{f}\left(X_{i}, \beta\right) \exp \left(V_{i}\right)
$$

Where,

$Y^{*}=$ The frontier output

Rewrite equation (1) using equation (3) gives:

$$
Y=Y^{*} \exp (U)
$$


Therefore, the technical efficiency of an individual farmer can be given as:

$$
T E=\frac{\mathrm{f}\left(X_{i}, \beta\right) \exp \left(V_{i}-U_{i}\right)}{\mathrm{f}\left(X_{i}, \beta\right) \exp \left(V_{i}\right)} \text { Therefore, } T E=\frac{Y}{Y^{*}}
$$

It implies that the difference between observed output (Y) and frontier output $\left(\mathrm{Y}^{*}\right)$ is embedded in $\mathrm{U}$ when $\mathrm{U}=0$, then $\mathrm{I}$ production is in the frontier (i.e., $\mathrm{Y}=\mathrm{Y}^{*}$ ) and the farmer is said to be technically efficient. However, if $U>0$, the farmer is inefficient since production will lie below the frontier $(19,20)$.

The variance parameters are expressed as:

$$
\sigma_{u}^{2}+\sigma_{v}^{2}
$$

$$
C=\frac{\sigma_{u}^{2}}{\sigma_{v}^{2}}
$$

Where,

$\mathrm{C}$ ranged from $0-1$. When $\mathrm{C}=1$, it implies that all deviations are due to technical inefficiency (19). Following(19) and has adopted by (15) and(20), a CobbDouglas production function, was fitted to the stochastic frontier function and estimated. The Cobb-Douglas functional form has been consistently used in similar efficiency studies (21). It is also possible to use more flexible form such as translog production function. However, according to (22), functional forms have been shown to have limited effect on empirical efficiency measurement.

Explicitly, the production function was stated as:

$$
\operatorname{Ln} Y_{i}=\beta_{0}+\beta_{1} \ln X_{1}+\beta_{2} \ln X_{2}+\beta_{3} \ln X_{3}+\beta_{4} \ln X_{4}+v_{i}-u_{i}
$$

Where,

$\mathrm{InY}_{\mathrm{i}}=$ Natural logarithm of total number of eggs produced by farmer $\mathrm{i}$

$\mathrm{X}_{1}=$ number of layers kept

$\mathrm{X}_{2}=$ quantity of feed $(\mathrm{kg})$

$\mathrm{X}_{3}=$ labour (man days)

$\mathrm{X}_{3}=$ quantity of drugs $(\mathrm{kg})$

$\beta_{0}=$ constant

$\beta^{`} \mathrm{~s}=$ parameters to be estimated

$\mathrm{V}_{\mathrm{i}}$ is a random variable which is assumed to be identically and independently distributed normal $\left\{\mathrm{N}\left(0, \sigma_{\mathrm{V}}{ }^{2}\right)\right\}$, and independent of the $\mathrm{U}_{\mathrm{i}}$;

$\mathrm{U}_{\mathrm{i}}$ is a non-negative random variable, which is assumed to account for technical inefficiency in production and is assumed to be independently distributed as truncation at zero of the $\mathrm{N}\left(\mu_{\mathrm{i}}, \sigma_{\mathrm{U}}^{2}\right)$ distribution; for

\subsubsection{Technical Inefficiency}

Technical inefficiency effect is the result of behavioral factors which could be controlled by efficient management (21). Some farmers' as well as farm specific characteristics were included in the frontier function. The assumption is that they have direct influence on efficiency. The efficiency model is therefore implicitly specified as:

$$
\mu_{i}=\delta_{0}+\sum_{i=1}^{8} \delta_{i} G_{i}+\omega_{i}
$$

Where,

$\mathrm{G}_{\mathrm{i}}=$ is a $\mathrm{p} \times 1$ vector of variables hypothesized as having influence on technical efficiency of the farmers. They include:

$\mathrm{G}_{1}=$ age (years)

$\mathrm{G}_{2}=$ poultry farming experience (years)

$\mathrm{G}_{3}=$ education (years)

$\mathrm{G}_{4}=\operatorname{sex}$ (male $=1,0$ otherwise)

$\mathrm{G}_{5}=$ membership of cooperative society (yes $=1,0$ otherwise)

$\mathrm{G}_{6}=$ management system (battery cage system $=1,0$ otherwise)

$\mathrm{G}_{7}=$ stock type (one - day - old - chicks $=1,0$ otherwise)

$\mathrm{G}_{8}=$ farm ownership status (owner $=1,0$ otherwise)

$\delta_{0}=$ constant $\delta$ 's = parameters to be estimated

$\omega=$ composite error term

\section{Results and Discussion}

\subsection{Socioeconomic Characteristics of the Respondents}

A descriptive analysis of the socio-economic characteristics of the respondents is presented in Table 1. The results show that about halve of poultry farmers in Ibadan metropolis were in the range $41-50 y e a r s$. The findings are consistent with those of (23). The majority of the respondents were male $(88.8 \%)$ and married $(90.7 \%)$.All the poultry egg farmers in the study area are educated with about $50 \%$ of them having secondary education; thus, this will enhance the management of poultry farms in the study area. This is however, contrary to the submission of (24), (1) but in line with the findings of $(23,25)$. The cosmopolitan nature of Ibadan which is seen as the convergent zone for all Yorubas in the southwestern part of the country may however, be responsible for these group of farmers who are more educated than their counterparts in rural areas.

More than halve of the respondents have family members between 4-6 members. The households in the sample tended to be a bit larger than the recommended national average, five members on average compared to the average of four recommended (26). However, (16), opines that the large family size enables farmers to use family labour most especially when labor-intensive techniques are required. The results show that poultry farmers having 6-10 years of experience constitutes majority of the respondents while only very few of them have been in poultry farming for over 20 years. The mean years of experience stood at 12. It is in consonance with (14) who finds that layer farmers are relatively young in the business.

On cooperative society membership, well above threequarter of the poultry egg farmers were members of cooperative societies. Membership of cooperative society assists in solving members' problems. The finding concurs with the submission of (24), but contradicts the findings of 
(23) who showed that the majority of the farmers did not join cooperative societies due to cultural and religious beliefs. This may not be unconnected with the fact that the majority of the respondents are small- to- medium scale farmers. It is becoming more difficult for this category of farmers to access loan from financial institutions. About $68 \%$ of poultry egg farmers in Ibadan city stocked their farms with a - Day- Old Chicks (DOCs) while the remaining preferred Point of Lay (POL). This may be due to the fact that initial capital required to stock the farm with layers is higher in POL compare with DOC and these farmers may not have the huge capital required, hence, higher number going for DOC. Also, raising the layers by the farmers from a - day- old may give them a level of confidence about the necessary vaccinations and feeds required by the birds when they are young. Table 1 further shows that about two-third of the respondents own the poultry farms while others raised their layers on rented apartment.

Table 1. Distribution of respondents by socio-economic characteristics.

\begin{tabular}{|c|c|c|}
\hline Variables & Frequency & Percent \\
\hline \multicolumn{3}{|l|}{ Age } \\
\hline Below 30 years & 1 & 0.9 \\
\hline $31-40$ years & 34 & 31.8 \\
\hline $41-50$ years & 48 & 44.9 \\
\hline $51-60$ years & 24 & 22.4 \\
\hline \multicolumn{3}{|l|}{ Sex } \\
\hline Male & 95 & 88.8 \\
\hline Female & 12 & 11.2 \\
\hline \multicolumn{3}{|l|}{ Marital status } \\
\hline Single & 1 & 0.9 \\
\hline Married & 97 & 90.7 \\
\hline Widow & 1 & 0.9 \\
\hline Separated & 8 & 7.5 \\
\hline \multicolumn{3}{|l|}{ Years of schooling } \\
\hline $1-6$ & 11 & 10.3 \\
\hline $7-12$ & 60 & 56.0 \\
\hline$>12$ & 36 & 33.6 \\
\hline \multicolumn{3}{|l|}{ Household size } \\
\hline $1-3$ & 34 & 31.8 \\
\hline $4-6$ & 54 & 50.5 \\
\hline $7-9$ & 13 & 12.1 \\
\hline $10-12$ & 6 & 5.6 \\
\hline \multicolumn{3}{|l|}{ Years of experience } \\
\hline Below 5 & 32 & 29.9 \\
\hline $6-10$ & 36 & 33.6 \\
\hline $11-15$ & 31 & 29.0 \\
\hline $16-20$ & 6 & 5.6 \\
\hline Above 20 & 2 & 1.9 \\
\hline \multicolumn{3}{|l|}{ Membership of cooperative } \\
\hline Members & 93 & 86.9 \\
\hline Non-members & 14 & 13.1 \\
\hline \multicolumn{3}{|l|}{ Stock type } \\
\hline Day - old - chicks (DOCs) & 73 & 68.2 \\
\hline Point - of - lay (POL) & 34 & 31.8 \\
\hline \multicolumn{3}{|l|}{ Poultry farm ownership } \\
\hline Owned the farm & 65 & 60.7 \\
\hline Rent the farm & 35 & 39.3 \\
\hline \multicolumn{3}{|l|}{ System of management } \\
\hline Battery cage system & 38 & 35.5 \\
\hline Deep litter system & 62 & 64.5 \\
\hline Total & 107 & 100.0 \\
\hline
\end{tabular}

\subsection{Production Efficiency Model Estimates for Poultry Egg Production}

The results of factors affecting production efficiency in egg production in the study area are presented in Table 2. As shown in the table, the estimated sigma squared $\left(\delta^{2)}\right.$ parameter (1.02) in the stochastic frontier function is significantly different from zero at $1 \%$, implying a good fit of the model and the correctness of the specified distributional assumptions. Also, the estimated gamma $(\Gamma)$ parameter (10.91) is significant at $1 \%$ indicating that the production inefficiency effects are significant in determining the level and variability of layer production in Ibadan. The observed variations in production efficiency among the poultry egg farmers are due mainly to differences in farm practices and characteristics of the respondents rather than random factors.

The quantity of feed used in feeding the birds is positive and significant at $1 \%$, implying that increase in the quantity of feed fed to layers will result in significant increase in their outputs all other things being equal. The result is in line with the findings of (27 and 15). The quantity of drugs and vaccines administered on the birds is significant but negative at $1 \%$ indicating that increase in the quantity of drugs and vaccines administered will lead to reduction in number of eggs produced ceteris paribus. This may be due to the fact that some of the drugs (anticoccidial) reduce reproductive performance (28); more importantly, the result is an indication that poultry farmers in the study area patronized quack veterinary vendors. The results however, contradict with the findings of (26), (29), and (16) who reported a positive and significant relationship between medicine/vaccine and output in their respective poultry efficiency studies.

\subsection{Determinants of Technical Inefficiency}

The MLE results of the determinants of technical efficiency of the poultry egg farmers in the study area are shown in Table 2. Concerning the signs of the coefficient of inefficiency variables, they are important in explaining the level of observed production efficiency among poultry egg producers. A negative sign implies that the variable has the effect of reducing technical inefficiency whilst a positive sign has the effect of increasing it. The results of the sources of the inefficiencies has presented in Table 2 shows that the coefficient for experience variable is positive and significant at 5\% level. This implies that, layer producers who have more years in the farming business are more inefficient technically compares with the less experienced ones. This may be due to the fact that the more experienced producers may tend to rely on their technical know-how and thereby, tend to shun any innovative ideas being brought forward. The young ones may tend to learn more and thereby, look forward to embracing the new technologies and ideas; hence, may tend to be more efficient than the older respondents. This finding is in accordance with those of (10), 30, 31 and (16) but contradicts those of (32), (33)and(34) who opined that the more experienced the poultry egg farmer is, the more 
efficient the producer becomes.

Table 2. Maximum Likelihood Estimates (MLE) of the stochastic frontier production function for poultry egg production.

\begin{tabular}{|c|c|c|c|c|}
\hline Variables & Parameters & $\begin{array}{l}\text { MLE } \\
\text { coefficient }\end{array}$ & $\begin{array}{l}\text { Standard } \\
\text { error }\end{array}$ & t-ratio \\
\hline Constant & $\beta_{0}$ & 16.44 & 1.3 & 12.65 \\
\hline Flock size & $\beta_{1}$ & 0.01 & 0.08 & 0.13 \\
\hline Feed quantity & $\beta_{2}$ & $0.09 * * *$ & 0.03 & 3.00 \\
\hline Labour & $\beta_{3}$ & 0.01 & 0.11 & 0.09 \\
\hline Drug quantity & $\beta_{5}$ & $-0.26 * * *$ & 0.07 & -3.71 \\
\hline $\begin{array}{l}\text { Inefficiency model } \\
\text { Constant }\end{array}$ & $\delta_{0}$ & $-3.53 * * *$ & 0.90 & -3.92 \\
\hline Age & $\delta_{1}$ & 0.41 & 0.56 & 0.73 \\
\hline Experience & $\delta_{2}$ & $0.19 * *$ & 0.08 & 2.40 \\
\hline Education & $\delta_{3}$ & -0.73 & 2.48 & -0.29 \\
\hline Sex & $\delta_{4}$ & 0.28 & 0.66 & 0.42 \\
\hline $\begin{array}{l}\text { Membership of } \\
\text { cooperative society }\end{array}$ & $\delta_{5}$ & $-0.07 * *$ & 0.03 & -2.33 \\
\hline $\begin{array}{l}\text { System of } \\
\text { management }\end{array}$ & $\delta_{6}$ & $-0.09 * *$ & 0.04 & -2.25 \\
\hline Stock type & $\delta_{7}$ & $-0.52 *$ & 0.30 & -1.74 \\
\hline $\begin{array}{l}\text { Farm ownership } \\
\text { status }\end{array}$ & $\delta_{8}$ & 0.15 & 0.11 & 1.36 \\
\hline Sigma -Squared & $\delta^{2}$ & $1.02 * * *$ & 0.17 & \\
\hline Gamma & $\Gamma$ & 10.91 & 2.58 & \\
\hline
\end{tabular}

Note:* significant at $10 \%, * *$ significant at $5 \%$ and $* * *$ significant at $1 \%$

The results (Table 2) show that membership of cooperative society is negatively associated with farmers' technical inefficiency at 5\% level. This implies that respondents that belong to cooperative society in addition to being members of PAN tend to be more technical efficient than their counterparts who are non-cooperators. This perhaps, may be as a result of benefits derived from been members of cooperative societies such as participation in seminars, workshops and other training activities, share ideas and information with other egg producers. These tend to improve upon their managerial capability and efficiency, hence, improving their technical efficiency. This finding supported the earlier results obtained by $(19,35$ and 16). The stock type and system of layer management have the expected negative signs and significant at $10 \%$ and $5 \%$ respectively. The implication is that the poultry egg farmers who got their stock from a - day- old with battery cage system of management are less technically inefficient than those who stocked their farms with point of lay and are raising their layers on deep litter.

\subsection{Technical Efficiency Indices}

The technical efficiency distribution of the respondents is presented in Table 3. The analysis shows that more than halve $(57 \%)$ of the respondents fall between the efficiency class of $0.61-0.80$, while about $12 \%$ of them have efficiency class of between $0.81-1.00$, suggesting that only about $69 \%$ of the respondents are operating close to the frontier. This is however lower than about $75 \%$ obtained by $(15)$. The mean technical efficiency of the farmers stood at 0.58 , signifying moderate efficiencies in poultry egg production in the study area. The implication is that there exists above $40 \%$ potential for respondents to increase their egg production as well as their income given the current level of technology. It also follows that if the poultry egg producers in the study area are efficient, they can increase the number of eggs been produced by $42.3 \%$ ceteris paribus.

Table 3. Distribution of technical efficiency of poultry egg producers in Ibadan.

\begin{tabular}{lll}
\hline Technical efficiency class & Frequency & Percentage \\
\hline$<0.21$ & 4 & 3.7 \\
$0.21-0.40$ & 10 & 9.3 \\
$0.41-0.60$ & 19 & 17.8 \\
$0.61-0.80$ & 61 & 57.0 \\
$0.81-0.99$ & 13 & 12.2 \\
Total & 107 & 100.0 \\
Mean & 0.58 & \\
Minimum & 0.17 & \\
Maximum & 0.92 & \\
\hline
\end{tabular}

\section{Conclusion and Recommendations}

The study shows that poultry egg production in the study area was technically inefficient, since none of the farmer sampled attained $100 \%$ technical efficiency. Hence, there are rooms for improvement in the productivity of the farmers. It is evident from this study that poultry egg production in Ibadan can be enhanced through feeding of the layers with adequate quantity of feed. Provision of high quality feed in right quantity should be ensured if egg production in Ibadan is to be improved upon. Also, drugs negatively impacted poultry egg production; Prophylactic rather than therapeutic measure in form of bio-security on the farms for disease control is recommended. This will not only help in reducing the quantity of drugs administered but also reduce the costs of drugs and veterinary services. The following are also recommended based on the findings of the study:

i. Intensifying training of the farmers by extension agents on the new management practices involved in poultry egg production and benefits of being members of cooperative society in addition to their membership of PAN.

ii. The study also suggests that government should come to the aid of poultry egg farmers through provision of interest free loans to be able to keep their layers in battery cage which is capital intensive. The loan can be made available to them through Poultry Association of Nigeria, Oyo state chapter.

\section{References}

[1] National Bureau of Statistics (NBS) (2014). Social Statistics in Nigeria. Federal Republic of Nigeria. 
[2] United States Department of Agriculture (USDA), (2013). International egg and poultry review. February 7, 16:8.

[3] Nasiru, M., Haruna, U.,Garba, A., \&Tafawa, A. (2012). Economics of Livestock Marketing in Gamawa Local Government Area, Bauchi State, Nigeria.In 2012 Eighth AFMA Congress, November 25-29, 2012, Nairobi, Kenya (No. 159412).African Farm Management Association (AFMA).

[4] Abedullah, A., Maqbool A., and Bukhsh, K. (2007). Issues and economics of poultry production: A case study of Faisalabad, Pakistan. Pakistan Veterinary Journal, 27:1.25-28.

[5] Apantaku, S. O. (2006). Analysis of participation of farmers in participatory poultry production research in Lagos State, Nigeria. Livestock Research for Rural Development 18(7). Retrieved from Retrieved from http://www.lrrd.org/lrrd18/7/apan18094.htm 7 April 2015.

[6] Australian Centre for International Agricultural Research (ACIAR).(2009). Improving village chicken production: A manual field workers and trainers, The Monograph series. 30$31 \mathrm{pp}$.

[7] Food and Agriculture Organization. (2005). Animal production and health, paper 50, FAO, Rome

[8] Tijani, A. A., Alimi, T., and Adesiyan, A. T. (2006). Profit Efficiency among Nigerian Poultry Egg Farmers. Research Journal of Agricultural and Biological Sciences, 2:6.256-261.

[9] Rahji, M. A.Y. (2005). Determinants of efficiency differentials in lowland rice production systems in Niger state, Nigeria. Ibadan Journal of Agricultural Research 1:1.7-17.

[10] Effiong, E. O., and Onyenweaku, C. E. (2006). Profit efficiency in Broiler Production in Akwa Ibom State. International Journal of Agriculture and Rural development, 7,72-79.

[11] Ashagidigbi, W. M., Sulaimon, S. A. and Adesiyan A. (2011). Technical efficiency of egg production in Osun State. International Journal of Agricultural Economics and rural development. 4:6.120-131.

[12] Ajibefun, I. A., Battese, G. E. and Daramola, A. G. (2002). Determinants of technical efficiency in Small holder food crop farming: Application of stochastic frontier production function. Q. J. Int. Agric. 41:225-240.

[13] Yusuf, S. A. and Malomo, O. (2007). Technical efficiency of poultry egg production: A Data Envelopment Analysis (DEA) approach. International journal of Poultry Science, 6:622-629

[14] Ojo, S. O. (2003). Productivity and technical efficiency of poultry egg production in Nigeria. International Journal of Poultry Science 2:459 - 464 .

[15] Binuomote, S. O., Ajetomobi, J. O and Ajao, A. O. (2008). Technical efficiency of poultry egg producers in Oyo State, Nigeria. International Journal of Poultry Science 7:1227-1231.

[16] Adepoju, A. A. (2008). Technical efficiency of egg production in Osun State. International Journal of Agricultural Economics and Rural Development 1:1.7-14.

[17] National Population Commision (NPS) (2006). National Population Census report, Nigeria.

[18] Olowofeso, O. E. and Ajibefun, I. A. (1999). The maximum likelihood estimation of stochastic frontier production functions with technical efficiency using Time series data.
Journal of Science and Engineering Tech. 6:1527-1536.

[19] Idiong, I. C. (2007). Estimation of farm level technical efficiency in Small scale Swamp rice production in Cross River State of Nigeria: A stochastic frontier approach. World Journal of Agricultural Sciences, 3(5), 653-658.

[20] Otunaiya, A. O., and Adedeji, I. A. (2014).Technical Efficiency of Watermelon (Citrullus Lanatus) Production in Ogun State, Nigeria. International Journal of Applied Agricultural \& Apicultural Research,10 (1\&2): 44-53.

[21] Xu, X. and Jeffrey, S. R. (1998). Efficiency and technical progress in traditional and modern agriculture, evidence from Rice production in China. Agricultural Economics Journal18:157-165.

[22] Belbase, K. and Grabowski, R.(1995). Technical Efficiency in Nepalese Agriculture. J. Dev. Areas 19:515-525.

[23] Nmadu, J. N., Ogidan, I. O. and Omolehin, R. A. (2014). Profitability and Resource Use Efficiency of Poultry Egg Production in Abuja, Nigeria. Kasetsart J. (Soc. Sci) 35:134 146.

[24] Hamid, M. Y., and Chiaman, E. S. (2010). Risk and uncertainty assessment of nomadic cattle pastoralists in MubiNorth Local Government Area, Adamawa State, Nigeria.Proceedings of 11th Annual National Conference of National Association of Agricultural Economists (NAAE) 30 November -3 December 2010 pp 109-113.

[25] Alhassan, S. (2008). Technical efficiency of rice producers in Northern Ghana. African Economic Research Consortium, Nairobi. Research paper 178.

[26] Alabi, R. A. and Haruna, M. B. (2005). Technical Efficiency of Family Poultry Production in Niger-Delta. Journal of Central European Agriculture6:4: 531-538.

[27] Oji, U. O., \& Chukwuma, A. A. (2007). Technical Efficiency of Small Scale Poultry-Egg Production in Nigeria: Empirical Study of poultry producers in Imo State, Nigeria. Research Journal of poultry Sciences, 1:3-4.16-21.

[28] Jacob, J. P., Wilson, H. R., Miles, G. D. Butcher, R. D. and Mather F. B. (2014). Factors Affecting Egg Production in Backyard Chicken Flocks. U.S. Department of Agriculture, UF/IFAS Extension Service, University of Florida, IFAS, Florida A \& M University Cooperative Extension Program, and Boards of County Commissioners Cooperating. Nick T. Place, dean for UF/IFAS Extension (FACT SHEET PS35FACT SHEET PS-35) http://edis.ifas.ufl.edu.Retrieved On 25/4/15.

[29] Ohajianya, D. O. (2005). Economic efficiency among small scale poultry farmers in Imo State, Nigeria. A stochastic Frontier Production Model Approach. International Journal of Agriculture and Rural Development 6:19-25.

[30] Begum, I. A., Buysse, J., Alam, M. J., and Huylenbroeck, G. V. (2009). An application of Data Envelopment Analysis (DEA) to evaluate Economic Efficiency of Poultry Farms in Bangladesh, Paper presented at the International Association of Agricultural Economists Conference, Beijing, China, August 16-22.

[31] Onumah, E. E. and Acquah, H. D. (2010). Frontier Analysis of Aquaculture Farms in the Southern Sector of Ghana. World Applied Sciences Journal, 9:7.826-835. 
[32] Rahman, S. (2003). Profit efficiency among Bangladeshi rice producers. Food Policy 28, 483-503.

[33] Sharma, K. R., PingSun, L., and Halina M. Z. (1999). Technical, allocative and economic efficiencies in swine production in Hawaii: a comparison of parametric and nonparametric approaches. Agricultural Economics20:23-35.
[34] Adesiyan, A., Sulaiman, S. A., \&Ashagidigbi, W. M. (2011). Technical and Allocative Efficiency of Poultry Egg Producers in Nigeria. Agricultural Journal 6:4.124-130.

[35] Galawat, F. and Yabe, M. (2012). Profit Efficiency in Rice Production in Brunei Darussalam: A Stochastic Frontier Approach. J. ISSAAS, 18:1.100-112. 